\title{
Sifat Organoleptik dan Kadar Serat Pangan Mie Basah dengan Penam- bahan Tepung Okra Hijau (Abelmuschus esculentum L.)
}

\author{
Agustiana $^{1}$, Waluyo ${ }^{2}$, Fery Lusviana Widiany ${ }^{1 *}$ \\ ${ }^{1}$ Program Studi Ilmu Gizi, Fakultas Ilmu Kesehatan, Universitas Respati Yogyakarta, \\ Yogyakarta. \\ ${ }^{2}$ Jurusan Gizi, Politeknik Kesehatan Kementerian Kesehatan, Yogyakarta. \\ *lusviana86@gmail.com
}

\begin{abstract}
The content of dietary fiber in wet noodle is lower than the dietary fiber requirement, so we need to add the local food which is high in dietary fiber content, that is green okra (Abelmuschus esculentum L). This study was to determine the effect of green okra flour mixing in wet noodle on organoleptic characteristics and dietary fiber content. This was an experimental study with complete random design. The independent variable was substitution of green okra flour on wet noodle, while the dependent variables were organoleptic characteristics and dietary fiber content. There were four variations of wet noodles i.e. 0\%, 10\%, 15\%, 20\%. Data were analyzed using Kruskal-wallis, Mann Whitney and Anova. The result showed wet noodle 10\% was whitish green, typical flavour of wet noodle, and chewy. The highest level of dietary fiber content was in wet noodle 20\% as many as 9,92 grams. In conclusion, there were any significant differences in organoleptic test result based on aroma and taste, but no difference based on color and texture. There were significant differences in dietary fiber content from the four experiment variations. The higher percentage of green okra flour makes the higher content of dietary fiber content in wet noodles.
\end{abstract}

Keywords : Wet noodle; Green okra (Abelmuschus esculentum L.) flour; Organoleptic characteristic; Dietary fiber content. 


\section{PENDAHULUAN}

Konsumsi sayur dan buah diperlukan tubuh sebagai sumber vitamin, mineral dan serat dalam mencapai pola makan sehat sesuai anjuran pedoman gizi seimbang untuk kesehatan yang optimal (Kementerian Kesehatan Republik Indonesia, 2014). Sebagian vitamin dan mineral yang terdapat dalam sayur dan buah mempunyai fungsi sebagai antioksidan sehingga dapat mengurangi kejadian penyakit tidak menular terkait gizi, sebagai dampak dari kelebihan atau kekurangan gizi (Afriansyah, 2008).

Riskesdas tahun 2013 menunjukkan bahwa secara nasional perilaku penduduk umur $>10$ tahun yang kurang mengonsumsi sayur dan buah masih di atas $90 \%$. Kondisi ini sejalan dengan temuan hasil Survei Konsumsi Makanan Individu (SKMI) dalam Studi Diet Total bahwa konsumsi penduduk terhadap sayur dan olahannya serta buah dan olahannya masih rendah (Badan Penelitian dan Pengembangan Kesehatan, 2014). Rata-rata konsumsi serat penduduk Indonesia secara umum yaitu 10.5 g/hari (Departemen Kesehatan Republik Indonesia, 2008). Padahal kecukupan serat yang dianjurkan berdasarkan golongan usia remaja dan dewasa, yakni sebesar 30-38 gram untuk laki-laki dan 28-32 gram untuk perempuan (Kementerian Kesehatan Republik Indonesia, 2013).

Kurangnya konsumsi sayur dan buah dapat mengakibatkan berbagai dampak yaitu memicu perkembangan obesitas, karena sayur dan buah merupakan makanan yang rendah kalori dan kaya akan serat yang akan menghambat terjadinya penimbunan lemak pada tubuh sehingga buah dan sayur memiliki berbagai manfaat bagi tubuh. Kurang mengkonsumsi buah dan sayur dapat mengakibatkan tubuh mengalami kekurangan zat gizi seperti vitamin, mineral, dan serat sehingga menimbulkan terjadinya berbagai penyakit (Manurung, 2009).

Penyakit yang dapat ditimbulkan antara lain sembelit, obesitas yang dapat menimbulkan risiko penyakit degeneratif termasuk diabetes mellitus. Diperlukan inovasi bahan makanan yang mengandung tinggi serat untuk mengantisipasi risiko penyakit degeneratif terkait kurangnya konsumsi serat, selain formula nasi kacang merah yang telah terbukti dapat meningkatkan daya terima pasien diabetes mellitus (Widiany, 2016). Alternatif pangan yang mengandung serat adalah okra.

Okra merupakan tanaman jenis sayuran yang menghasilkan polong yang dapat dikonsumsi. Tanaman okra merupakan salah satu jenis sayuran yang mengandung sedikit energi dan mengandung 3,2 gram serat per 100 gram berat dapat dimakan (BDD) (Roy, Shrivastava, Mandal, 2014) Tanaman okra juga disebut dengan gumbo karena hanya mengandung $30 \mathrm{kcal}$ energi dalam 100 gram BDD dan tidak mengandung lemak jenuh. Okra merupakan jenis sayuran yang kaya akan 
serat, vitamin, dan mineral. Sayuran okra ini dapat membantu kerja peristaltik pencernaan dan meringankan sembelit (Reaksohadiprojo, 2009). Okra dapat diolah menjadi berbagai macam olahan makanan, salah satunya mie basah.

Mie merupakan makanan yang sangat digemari mulai anak-anak sampai orang dewasa (Widyaningsih dan Murtini, 2006). Mie basah biasanya dibuat dari tepung terigu sebagai bahan bakunya, namun ternyata kadar serat dalam mie basah tersebut masih kurang. Salah satu alternatif dalam meningkatkan nilai gizi mie adalah dengan menambahkan tepung okra hijau (Bellina, Waluyo, Suhandy, 2014). Penambahan tepung okra hijau pada produk olahan mie basah ini, diharapkan akan memberikan alternatif produk yang mengandung kadar serat pangan tinggi sehingga dapat memenuhi kecukupan serat pada masyarakat. Penelitian ini dilakukan untuk mengetahui pengaruh pencampuran tepung okra hijau (Abelmuschus esculentum L.) pada pembuatan mie basah ditinjau dari sifat fisik, sifat organoleptik dan kadar serat pangan.

\section{METODE PENELITIAN}

Penelitian ini berjenis true eksperimental dengan rancangan acak lengkap dengan dua unit percobaan dan empat perlakuan. Empat perlakuan tersebut meliputi pencampuran tepung okra hijau dengan variasi $0 \%$, 10\%, 15\%, dan 20\%. Penelitian dilaksanakan pada bulan Januari - Maret 2018 di tiga tempat, yakni Laboratorium Dietetik dan Kuliner Universitas Respati Yogyakarta untuk pengeringan okra hijau dan pembuatan mie basah, Laboratorium Teknologi Pertanian Universitas Gadjah Mada untuk penepungan okra hijau, dan Laboratorium Chemix Pratama Yogyakarta untuk analisis kadar serat pangan.

Variabel independen penelitian ini adalah pencampuran tepung okra hijau (Abelmuschus esculentum L.) pada pembuatan mie basah, sedangkan variabel dependennya adalah sifat fisik, sifat organoleptik, dan kadar serat pangan. Uji sifat fisik dilakukan oleh peneliti, yang meliputi uji warna, rasa, aroma, dan tekstur. Uji organoleptik meliputi uji hedonik yang dilakukan oleh 25 panelis agak terlatih yaitu mahasiswa Program Studi Ilmu Gizi Universitas Respati Yogyakarta yang memenuhi kriteria inklusi diantaranya dapat menerima makanan bentuk mie basah, tidak mengalami alergi makanan, dan telah lulus mata kuliah Teknologi Pangan. Parameter yang diujikan dalam uji organoleptik adalah warna, aroma, rasa, dan tekstur. Penilaian uji organoleptik berskala interval, berdasarkan skoring yakni $1=$ sangat tidak suka, $2=$ tidak suka, 3=agak suka, 4=suka, 5=suka sekali, $6=$ sangat suka sekali. Analisis kadar serat pangan dilakukan dengan metode multienzim.

Data sifat organoleptik yang diperoleh dianalisis menggunakan uji Kruskal-Wallis, kemudian apabila data yang dihasilkan terdapat perbedaan, maka analisis dilanjutkan 
dengan uji Mann-Whitney. Data kandungan serat dianalisis menggunakan uji ANOVA. Analisis dilakukan menggunakan program statistik SPSS versi 21.

Penelitian ini telah memperoleh surat kelaikan etik dari Komisi Etik Penelitian Universitas Respati Yogyakarta dengan No.114.4/UNRIYO/PL/IV/2018.

\section{HASIL DAN PEMBAHASAN}

Formulasi mie basah dengan pencampuran tepung okra hijau disajikan pada Tabel 1. Setiap formulasi dari mie basah memiliki warna, aroma, rasa dan tekstur yang berbeda. Syarat mie basahyang baik memiliki kriteria yaitu berwarna putih atau kuning terang, tekstur agak kenyal dan tidak mudah putus (Standar Nasional Indonesia, 1992).
Tabel 1. Komposisi Bahan

\begin{tabular}{lccccc}
\hline \multicolumn{1}{c}{ Bahan } & Satuan & \multicolumn{3}{c}{ Perlak } \\
\cline { 2 - 6 } & & $\mathrm{A}$ & $\mathrm{B}$ & $\mathrm{C}$ & $\mathrm{D}$ \\
\hline Tepung okra hijau & $\mathrm{g}$ & 0 & 10 & 15 & 20 \\
Tepung terigu & $\mathrm{g}$ & 100 & 90 & 85 & 80 \\
Garam & $\mathrm{g}$ & 1 & 1 & 1 & 1 \\
Sodium tripoliphospat & $\mathrm{g}$ & 2 & 2 & 2 & 2 \\
Kuning telur & $\mathrm{g}$ & 25 & 25 & 25 & 25 \\
Air & $\mathrm{ml}$ & 50 & 50 & 50 & 50 \\
\hline
\end{tabular}

Sifat Organoleptik

Uji sifat organoleptik ini dilakukan untuk mengetahui tingkat kesukaan panelis terhadap warna, aroma, rasa, dan tekstur dari mie basah denga keempat variasi perlakuan. Hasil uji sifat organoleptik ditampilkan pada Tabel 2.

Tabel 2. Hasil Analisis Statistik Uji Organoleptik pada Mie Basah Menggunakan Uji Kruskall-Wallis

\begin{tabular}{|c|c|c|c|c|}
\hline \multirow{2}{*}{$\begin{array}{l}\text { Variasi pencampuran tepung okra } \\
\text { hijau pada mie basah }\end{array}$} & \multicolumn{4}{|c|}{ Mean Rank } \\
\hline & Warna & Aroma & Rasa & Tekstur \\
\hline $\begin{array}{l}\text { 0\% Tanpa pencampuran tepung okra } \\
\text { hijau }\end{array}$ & $51,52^{\mathrm{a}}$ & $57,80^{\mathrm{a}}$ & $62,76^{\mathrm{a}}$ & $51,00^{\mathrm{a}}$ \\
\hline Pencampuran tepung okra hijau $10 \%$ & $52,58^{\mathrm{a}}$ & $57,90^{\mathrm{a}}$ & $55,72^{\mathrm{a}}$ & $52,04^{\mathrm{a}}$ \\
\hline Pencampuran tepung okra hijau $15 \%$ & $50,44^{\mathrm{a}}$ & $47,80^{\mathrm{b}}$ & $46,16^{\mathrm{b}}$ & $47,68^{\mathrm{a}}$ \\
\hline Pencampuran tepung okra hijau $20 \%$ & $47,46^{\mathrm{a}}$ & $38,50^{\mathrm{b}}$ & $38,50^{\mathrm{b}}$ & $51,28^{\mathrm{a}}$ \\
\hline
\end{tabular}

Keterangan : Notasi huruf yang berbeda $\left({ }^{\mathrm{a}, \mathrm{b}_{\mathrm{dan}}}{ }^{\mathrm{c}}\right)$ pada kolom yang sama menyatakan terdapat perbedaan.

Tabel 2 menunjukkan hasil uji Kuskall-Wallis bahwa tidak ada perbedaan dari keempat variasi pencampuran tepung okra hijau terhadap sifat organoleptik mie basah berdasarkan warna dan tekstur, namun ada perbedaan berdasarkan aroma dan rasa. 
Warna merupakan suatu daya tarik tersendiri bagi panelis untuk dapat diterima sebagai bahan pangan yang baik dan mengandung nilai gizi yang bermanfaat bagi tubuh. Warna yang ditimbulkan dari pencampuran tepung okra hijau ke dalam komposisi pembuatan mie basah menimbulkan warna hijau, sehingga dapat meningkatkan antusias dari panelis untuk menikmatinya.

Berdasarkan uji statistik, penambahan tepung okra hijau pada pembuatan mie basah tidak berpengaruh terhadap tingkat kesukaan panelis dari mie basah yang dihasilkan. Hal tersebut disebabkan pencampuran tepung okra hijau dalam pembuatan mie basah menimbulkan warna hijau yang hampir seragam. Meskipun semakin banyak pencampuran tepung okra hijau menghasilkan warna yang semakin hijau tua atau pekat, namun ternyata tidak mempengaruhi perbedaan kesukaan panelis berdasarkan warna terhadap keempat variasi percobaan.

Warna hijau ini dihasilkan dari pigmen klorofil yang terkandung dalam okra, jika okra segar berwarna hijau tua, namun jika sudah diproses menjadi tepung, maka okra menjadi berwarna hijau muda atau kehijauan, sehingga dapat mempengaruhi warna dari mie basah. Perbedaan warna pada mie basah sangat dipengaruhi oleh pencampuran tepung okra hijau dan kuning telur digunakan sebagai pengemulsi karena dalam telur terdapat lesitin. Penambahan telur juga akan memberikan warna yang seragam pada mie basah $0 \%$ tanpa pencampuran tepung okra hijau. Secara indrawi warna hijau mie basah akan semakin meningkat dan pekat apabila proporsi pencampuran tepung okra hijau ditingkatkan.

Aroma merupakan suatu penilaian dari satu makanan yang diciptakan dari indera pembau atau hidung (Winarno, 2004). Pada penilaian aroma dapat menimbulkan berbagai perbedaan pendapat dikarenakan setiap individu memiliki pendapat terhadap aroma, namun setiap individu memiliki kesukaan yang berbeda-beda. Persentase kesukaan tertinggi berdasarkan aroma yaitu pada mie basah dengan pencampuran tepung okra hijau $10 \%$. Semakin tinggi proporsi pencampuran tepung okra hijau, akan mempengaruhi aroma mie basah dan mempengaruhi tingkat kesukaan panelis.

Penerimaan panelis terhadap makanan ditentukan oleh aroma dan rasa dari makanan, dimana aroma dan rasa dipengaruhi oleh bahan yang digunakan. Rasa merupakan sifat fisik yang dapat dinilai melalui indera pegecap. Penilaian rasa ini bertujuan untuk mengetahui rasa enak atau tidaknya rasa dari suatu makanan tersebut. Rasa suatu bahan pangan merupakan perpaduan antara cita rasa, aroma, warna, dan teksturnya.

Hasil uji organoleptik menunjukkan persentase tingkat kesukaan panelis tertinggi pada rasa mie basah $0 \%$ tanpa pencampuran tepung okra hijau. Hal ini disebabkan karena mie basah $0 \%$ tanpa pencampuran tepung okra hi- 
jau memiliki rasa khas mie basah asli dari bahan dasar pembuatan mie basah dan tidak ada campuran dari tepung okra hijau, pada mie basah $0 \%$ memiliki rasa yang gurih yang berasal kadar tepung terigu yang lebih banyak.

Tekstur merupakan penilaian mutu secara organoleptik menggunakan indera peraba. Berdasarkan hasil analisis, persentase tertinggi tingkat kesukaan panelis terhadap tekstur mie basah terdapat pada pencampuran tepung okra hijau 10\%. Perbedaan tingkat kesukaan pada mie basah yang dihasilkan berpengaruh terhadap tingkat kekenyalan dari mie basah. Tingkat kekenyalan pada mie basah dipengaruhi oleh kadar pati pada bahan yang digunakan, sehingga semakin tinggi kadar pati maka tingkat kekenyalan pada mie basah semakin tinggi.

Tepung okra hijau memiliki struktur lebih kasar jika dibandingkan dengan tepung

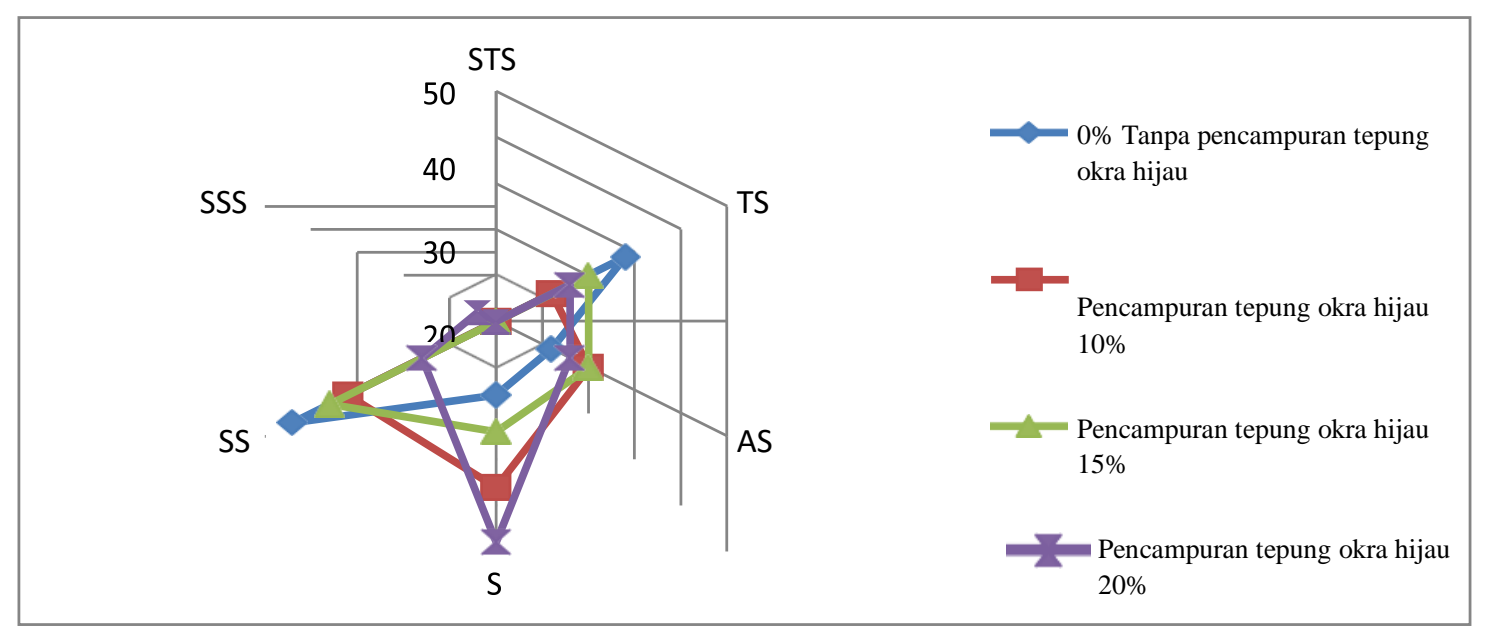

Gambar 1. Spider Web Tingkat Kesukaan Panelis Terhadap Warna Mie Basah

Berdasarkan Gambar 1, terlihat kurva dengan batas garis merah memiliki luas area paling besar dibandingkan garis batas lainnya. 
Artinya mie basah dengan pencampuran tepung okra hijau 10\% paling disukai berdasarkan warna dibandingkan variasi pencampuran yang lain.

\section{Aroma}

Tingkat kesukaan panelis terhadap aroma mie basah yang tertinggi terdapat pada mie basah $10 \%$ yaitu dengan skor total rata-rata 57,90.
Tingkat kesukaan panelis berdasarkan aroma mie basah memiliki perbedaan secara signifikan dari keempat variasi pencampuran tepung okra hijau. Hasil uji organoleptik panelis berdasarkan aroma mie basah ditampilkan dalam Spider Web pada Gambar 2.

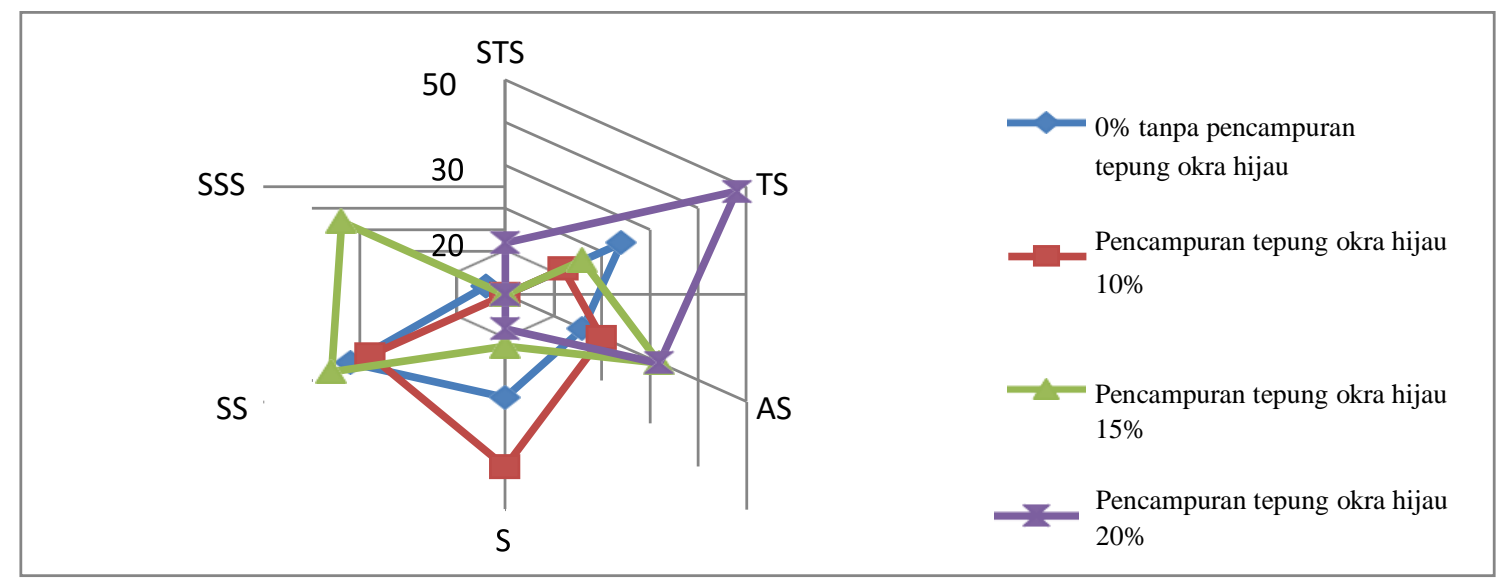

Gambar 2. Spider Web Tingkat Kesukaan Panelis Berdasarkan Aroma Mie Basah

Gambar 2 menunjukkan bahwa kurva dengan batas garis merah memiliki luas area paling besar dibandingkan garis batas lainnya. Artinya mie basah dengan pencampuran tepung okra hijau 10\% paling disukai berdasarkan aroma dibandingkan variasi pencampuran yang lain.

\section{Rasa}

Tingkat kesukaan panelis terhadap rasa mie basah yang tertinggi terdapat pada mie basah $0 \%$, yaitu total skor rata-rata 62,76 , diikuti variasi penambahan tepung okra $10 \%$ yaitu dengan total skor rata-rata 55,72. Terdapat perbedaan yang signifikan hasil uji organoleptik berdasarkan rasa mia basah dari keempat variasi pencampuran tepung okra. Hasil uji organoleptik berdasarkan rasa mie basah dengan pencampuran tepung okra hijau ditampilkan dalam Spider Web pada Gambar 3. 


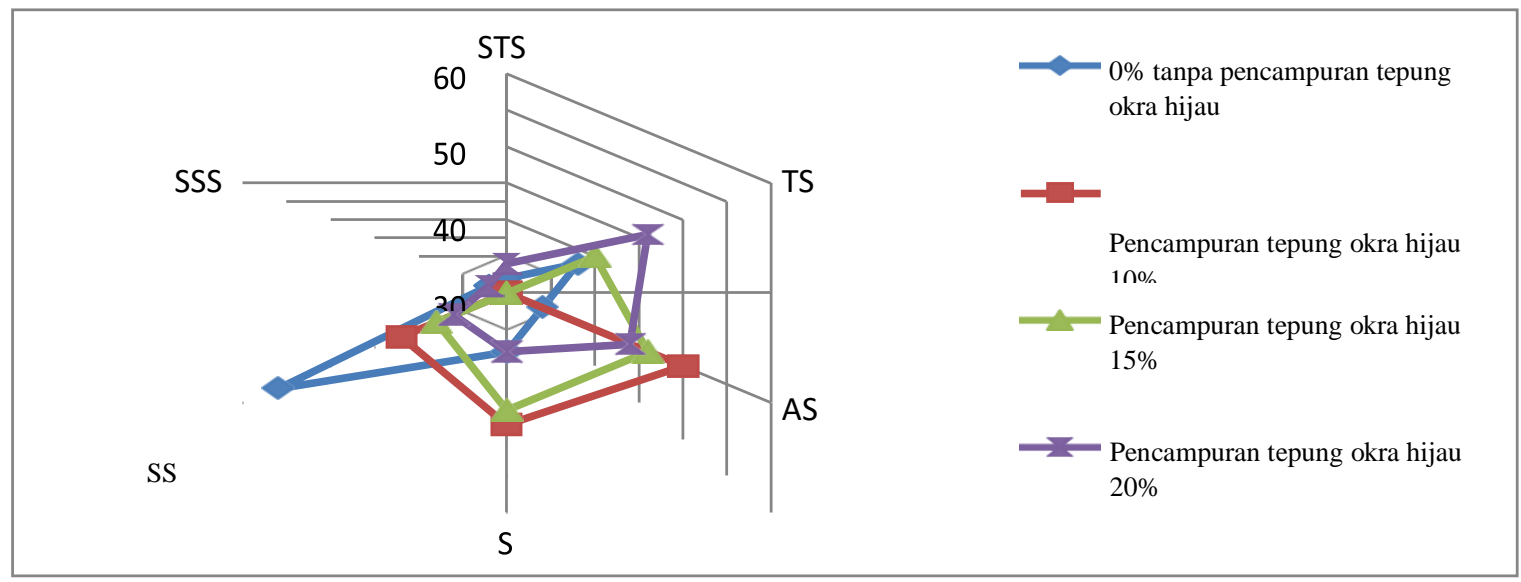

Gambar 3. Spider Web Tingkat Kesukaan Panelis Berdasarkan Rasa Mie Basah

Gambar 3 menunjukkan bahwa kurva dengan batas garis biru memiliki luas area paling besar dibandingkan garis batas lainnya. Artinya mie basah dengan pencampuran tepung okra hijau $0 \%$ paling disukai berdasarkan rasa dibandingkan variasi pencampuran yang lain. Kemudian diikuti luas kurva untuk garis batas merah, yaitu dengan pencampuran tepung okra $10 \%$ dalam pembuatan mie basah.

\section{Tekstur}

Tingkat kesukaan panelis terhadap tekstur mie basah yang tertinggi terdapat pada mie basah $10 \%$ yaitu dengan total skor rata-rata 52,04, namun tidak terdapat perbedaan signifikan secara statistik dari keempat variasi pencampuran tepung okra. Hasil uji organoleptik berdasarkan tekstur ditampilkan dalam Spider Web pada Gambar 4.

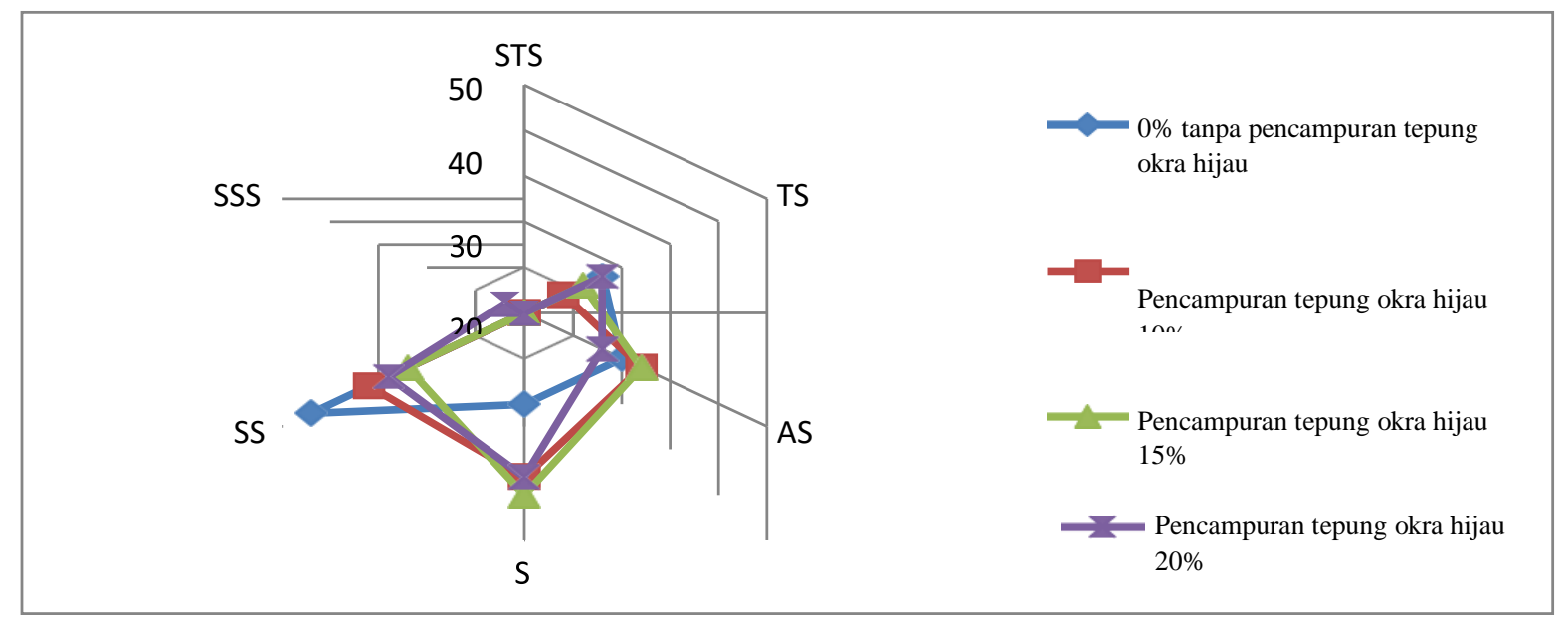

Gambar 4. Spider Web Tingkat Kesukaan Panelis Berdasarkan Tekstur Mie Basah 
Gambar 4 menunjukkan bahwa kurva dengan batas garis merah memiliki luas area paling besar dibandingkan garis batas lainnya. Artinya mie basah dengan pencampuran tepung okra hijau 10\% paling disukai berdasarkan tekstur dibandingkan variasi pencampuran yang lain.

\section{Kadar Serat Pangan}

Hasil analisis kadar serat pangan dari keempat variasi mie basah dengan pencampuran tepung okra hijau ditampilkan pada Tabel 4. Hasil analisis statistik menggunakan uji ANOVA menunjukkan $\mathrm{p}=0,000 \quad(p<0,05)$, yang berarti terdapat perbedaan secara signifikan kadar serat pangan pada keempat variasi pencampuran tepung okra hijau dalam pembuatan mie basah. Semakin banyak penambahan tepung okra hijau, maka kadar serat semakin tinggi. Kadar serat pangan tertinggi yaitu pada mie basah $20 \%$ sebesar $9,92 \%$.

Serat pangan adalah makanan berbentuk karbohidrat kompleks yang banyak terdapat pada dinding sel tanaman pangan. Serat pangan tidak dapat dicerna dan diserap oleh saluran pencernaan manusia, tetapi memiliki fungsi yang sangat penting bagi pemeliharaan kesehatan, pencegahan penyakit dan sebagai komponen penting dalam terapi gizi (Winarno, 2004).

Dari keempat variasi perlakuan menunjukkan ada perbedaan nyata pada setiap perlakuan dengan signifikan $(p=0,000)$. Kadar serat pangan tertinggi pada mie basah dengan pencampuran tepung okra hijau $20 \%$ sebesar $9,92 \%$. Semakin tinggi konsentrasi tepung okra hijau yang ditambahkan pada pembuatan mie basah, maka semakin tinggi kadar serat pangan pada produk mie basah tersebut.

Mie basah dengan pencampuran tepung okra hijau $10 \%$ berpotensi untuk dikembangkan menjadi makanan pengganti nasi, karena dari uji sifat fisik dan organolepitk sudah bisa diterima oleh panelis dan dalam 100 gram mie basah dengan pencampuran tepung okra hijau mengandung 5,78 gram kadar serat.

Pada penelitian ini telah diusahakan dan dilaksanakan sesuai dengan prosedur ilmiah, namun demikian masih memiliki keterbatasan penelitian, yakni dalam proses pemipihan mie basah yang kurang baik dan lengket pada penggiling mie basah. 
Tabel 4. Hasil Analisis Statistik Kadar Serat Pangan pada Mie Basah dengan Uji ANOVA

\begin{tabular}{lcc}
\hline $\begin{array}{l}\text { Variasi pencampuran tepung okra } \\
\text { hijau dalam pembuatan mie basah }\end{array}$ & $\begin{array}{c}\text { Rata- } \\
\text { rata } \\
\text { kadar } \\
\text { serat } \\
\text { pangan }\end{array}$ & $\begin{array}{c}\text { Nilai } \\
\text { p }\end{array}$ \\
\hline $\begin{array}{l}\text { 0\% tanpa pencampuran tepung okra } \\
\text { hijau }\end{array}$ & $4,75^{\mathrm{a}}$ & \\
Pencampuran tepung okra hijau & $5,78^{\mathrm{b}}$ & \\
$\begin{array}{l}10 \% \\
\text { Pencampuran tepung okra hijau }\end{array}$ & $6,93^{\mathrm{c}}$ & 0.000 \\
$\begin{array}{l}15 \% \\
\text { Pencampuran tepung okra hijau }\end{array}$ & $9,92^{\mathrm{d}}$ & \\
$20 \%$ &
\end{tabular}

Keterangan : Notasi huruf yang berbeda $\left({ }^{\mathrm{a}, \mathrm{b}, \mathrm{c}}\right.$ dan d) pada kolom yang sama menyatakan ada perbedaan nyata pada uji $L S D$

\section{SIMPULAN DAN SARAN}

\section{Simpulan}

Terdapat perbedaan yang signifikan terhadap hasil uji organoleptik berdasarkan aroma dan rasa, namun tidak terdapat perbedaan berdasarkan warna dan tekstur. Terdapat perbedaan signifikan kadar serat pangan dari keempat variasi percobaan. Semakin banyak persentase pencampuran tepung okra hijau, semakin tinggi pula kandungan serat dalam mie basah.

\section{Saran}

Diperlukan penelitian lebih lanjut mengenai kandungan zat gizi dalam okra dan diperlukan pengembangan makanan olahan terkait pemanfaatan okra.

\section{DAFTAR PUSTAKA}

Afriansyah, N. 2008. Rahasia Jantung Sehat dengan Makanan Berkhasiat. Jakarta :Penerbit Buku Kompas.

Astawan, M. 2006. Membuat Mie dan Bihun. Jakarta : Penebar Swadaya.

Badan Penelitian dan Pengembangan Kesehatan. 2014. Survei Konsumsi Makanan Individu dalam Buku Survei Diet Total Indonesia 2014: Laporan Nasional. Jakarta : Badan Penelitian dan Pengembangan Kesehatan.

Bellina, A., Waluyo, S., Suhandy, D. 2014. Kajian Sifat Fisik Mie Basah dengan Penambahan Rumput Laut. Jurnal Teknik Pertanian Lampung. Vol. 4 (2). 109-116.

Departemen Kesehatan Republik Indonesia. 2008. Kegemukan Akibat Kurang Serat. Cited at 15 November 2019. http://www.depkes.go.id .

Kementerian Kesehatan Republik Indonesia. 2013. Peraturan Menteri Kesehatan Republik Indonesia Nomor 75 Tahun 2013 tentang Angka Kecukupan Gizi yang Dianjurkan Bagi Bangsa Indonesia. Jakarta : Kementerian Kesehatan Republik Indonesia.

Kementerian Kesehatan Republik Indonesia. 2014. Pedoman Gizi Seimbang. Jakarta : Kementerian Kesehatan RI. 
Manurung, K.N. 2009. Pengaruh Karakteristik Remaja, Genetik, Pendapatan Keluarga, Pendidikan Ibu, Pola Makan dan Aktifitas Fisik terhadap Kejadian Obesitas Di SMU RK TRI Sakti Medan. Medan : Universitas SumatraUtara.

Reaksohadiprojo, S. 2009. Produksi Tanaman Hijauan Makanan Ternak Tropik. Yogyakarta : UGM Press.

Roy, A., Shrivastava, L.S., Mandal, M.S. 2014. Functional Properties Of Okra Abelmoschus esculentus L. (Moench): Traditional Claim And Scientific Evidence. Journal Plant Science Today. Vol. 1 (3). 121-130.
Standar Nasional Indonesia. 1992. Mi Basah SNI 01-2973-1992. Jakarta : Badan Standarisasi Nasional.

Widiany, F.L. 2016. Pemberian Formula Nasi Kacang Merah Efektif Meningkatkan Daya Terima Pasien Diabetes Mellitus. Jurnal Medika Respati. Vol. XI (3). 11-18.

Widyaningsih, T.B., Murtini, E.S. 2006. Alternatif Pengganti Formalin pada Produk Pangan. Surabaya : Trubus Agrisarana.

Winarno, F.G. 2004. Kimia Pangan dan Gizi. Jakarta : Gramedia Pustaka Utama. 